\title{
Thormation
}

Nordic Journal of Art and Research

ISSN: $1893-2479$

$\underline{\text { www.artandresearch.info }}$

\section{Between Contemporary Art and Cultural Analysis: Alternative Methods for Knowledge Production}

\author{
Billy Ehn ${ }^{1}$ \\ Department of Cultural and Media Studies, Umeå University
}

\begin{abstract}
Artistic research suggests alternative methods for producing various kinds of knowledge, whether within or without the confines of academe. These methods may involve either the production of investigative artworks or the writing by the artist of a doctoral dissertation about his or her own work. For cultural researchers, the methods employed by artists engaged in these processes are both familiar and challenging, as conventional ethnography is mixed with more unpredictable experiments. This article presents several contemporary artworks, including sculpture, film, dance, installation and performance that explore various aspects of reality. What can be learnt from these works? And what could be achieved by an open exchange between artists and academic researchers? Four methodological approaches are highlighted as being of particular interest. The first relates to artists' tendency to live experimentally, using themselves both as actors and as research objects. The second arises from the very tangible ways in which contemporary artworks approach the theme of materiality. The third relates to the emotional nature of much of contemporary art - even when it is categorised as conceptual - in its creation, forms of presentation, and influence on the spectator. Finally, many artists are gifted with the ability to find and communicate surprising meanings in ordinary life. How do they do this? Part of the answer seems to be that although artists are open to the implementation of "wild whims", they exploit their spontaneity in a highly professional manner.
\end{abstract}

Keywords: Artistic research, visual arts, knowledge production.

Interviewer: What have you tried to capture in your seventh symphony?

Allan Pettersson: Capture...? I just have... It is ... My music is my life, my own life, my way of living, blessed and damned life, nothing else.

From a radio interview with the Swedish composer Allan Petterson (1911-1980).

In the sculpture hall at the Museum of Art in Gothenburg there is a large "cannon" made of wood, metal and leather. Meticulously made by Ulf Rollof, it is titled Bälg IV (Bellows IV) (Fig. 1). On the floor lie two electrical motors, currently unplugged. A card on the wall contains the curator's

\footnotetext{
${ }^{1}$ Umeå University, SE-901 87 Umeå. E-mail: billy.ehn@kultmed.umu.se
} 
explanation of the sculpture: "With the curiosity and accuracy of a scientist Ulf Rollof has researched the riddles of life, whether they concern personal identity or the strangeness of the world around us".

Other sculptors in this hall are also compared to scientists. For example, Katrine Helmersson is described as "researching the tension between male and female, weak and strong, beautiful and threatening in dreamlike art objects. She investigates the relationships between material, object, space and spectator". Meanwhile Jone Kvies' artistic practice is described as "characterised by an investigation of the possibilities of sculpture. Her artworks often contain questions about the infinite nature of the universe and human efforts to understand and master the world".

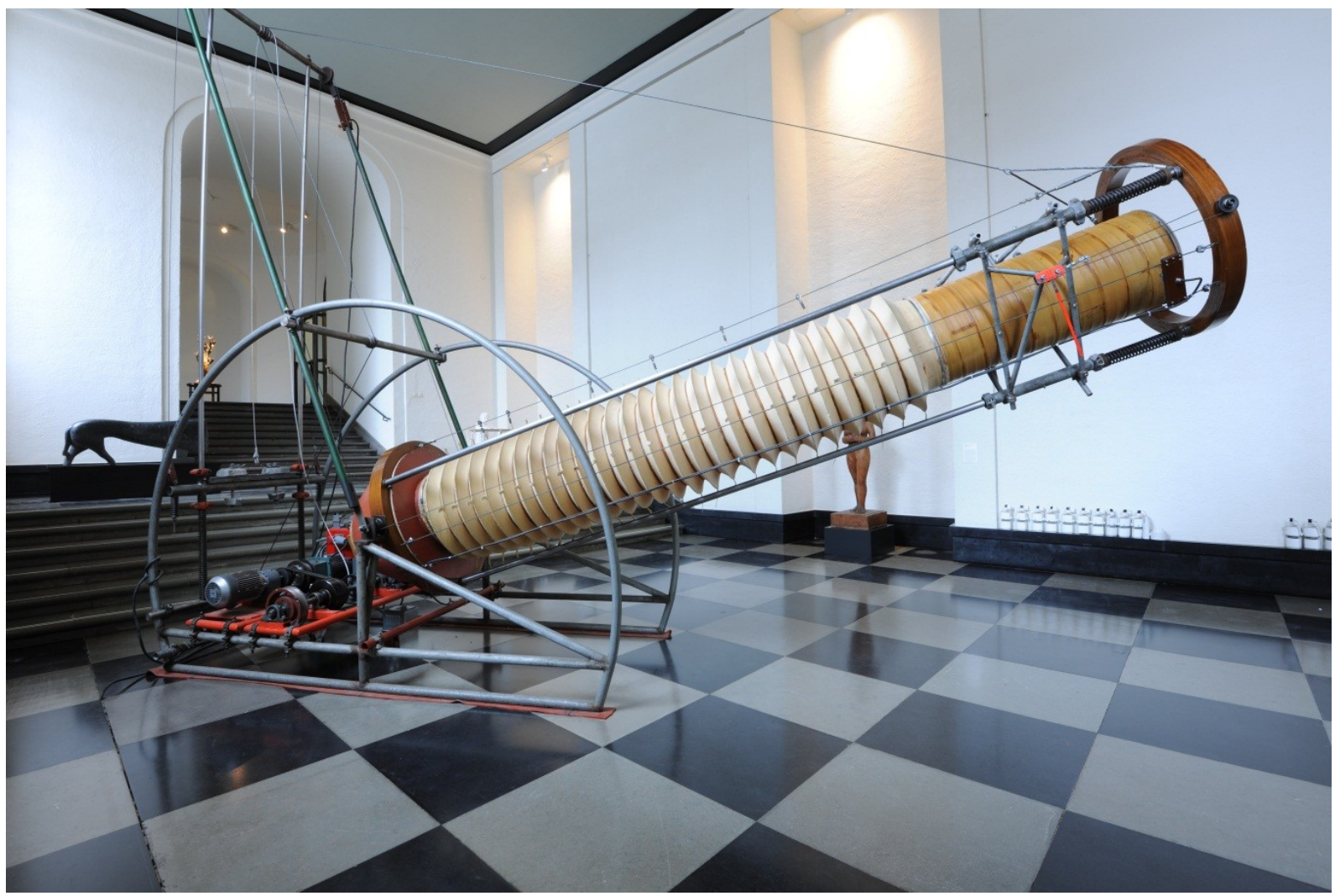

Figure 1. Ulf Rollof, Bälg IV, (1989)

\section{Experience and investigation}

As a cultural researcher, I can see at least two alternatives for approaching contemporary art. One is unrestrainedly to continue to experience art as an expression of life, the "blessed and damned", as the composer Allan Pettersson put it. The other involves reflecting on art in order to determine what it is that is being "captured". If Bälg IV and the other sculptures are about the riddles of life and the infinity of the universe, what is the meaning of this artistic research and how should it be undertaken?

In an ongoing project I am working with Orvar Löfgren, my colleague in European ethnology, to try to develop less conventional methods for ethnographic research and cultural analysis than those usually found in the textbooks. By combining various kinds of ethnographic materials (i.e., observations, conversations, informal surveys, newspaper reports, films and fiction), we are attempting - without getting caught up in the familiar - to capture the elusive and inconspicuous moments of everyday life. The use of such a bricolage method (Denzin \& Lincoln 2005: 4 et seq., Ehn \& Löfgren 
2011: 203 et seq.) in contemporary art is one source of inspiration. Accordingly we want to know what we can learn from the combination of unbridled creativity and sophisticated craft skills displayed by Ulf Rollof and other artists.

Although we already have used conceptual artworks as ethnographic examples, we have not previously thought about them explicitly as objects of artistic research (e.g., Ehn \& Löfgren 2010). However, when studying the materiality and expressivity of an elusive activity such as waiting for something to happen, we came across a performance piece by the Swedish artist Elin Wikström entitled Rebecka is waiting for Anna, Anna is waiting for Cecilia, Cecilia is waiting for Marie... Three female volunteers selected by the artist arrived at a café at scheduled times and waited there for 15 minutes. Each woman in turn sat at a table as though waiting for a date. Occasionally she looked at her watch, rummaged through her bag or read a magazine. At a prearranged time the woman would leave the café to be replaced by one of the other women, who would continue the everyday theatre of waiting for someone who never arrives.

In an interview Wikström said that she wanted this performance to present an alternative view of women. Commercials and films often depict women in a state of passive waiting: waiting to grow up, waiting for Mr. Right, waiting to have kids and waiting for their grown kids to come visit them. For once the artist wanted the women to be waiting for each other.

In another art project, this time in the form of the ballet Bahok by choreographer Akram Khan, eight men and women, stranded in a sterile airport terminal, are confined in a small transit space. The only connection with the outside world is a large monitor sending out messages such as "Delayed, Please Wait, Rescheduled, Cancelled". The ballet follows these eight individuals, with the dancers conveying the experience of being stuck in the middle of nowhere, with nothing to do but pass the time. In the meantime they try to communicate with the strangers next to them. On the stage the dancers give bodily expression to mixed feelings of boredom, frustration, and curiosity. Their movements intensify all the behaviours familiar to experienced travellers. Eventually these behaviours come totally to dominate the scene.

A third example was an installation by the British artist Hatty Lee. In a very minimalistic room, red seats are placed on a green synthetic carpet in front of plain white walls. A solitary flower pot in the corner attempts to provide distraction. This is the generic waiting room, where it is impossible to decide for what purpose one is expected to stay.

With rather simple means these three artists make us see and experience waiting as a physical activity that is permeated with many cultural meanings difficult to express by more conventional methods. ${ }^{2}$ Their capacity to see and display everyday life "with new eyes" has encouraged us to try to do likewise. We have also been inspired by their imagination and playfulness, as well as by "the artist's duty to be attentive to dreams and the unconscious" (Rist 2007: 45). But besides simply being

\footnotetext{
${ }^{2}$ In an e-mail, the artist and writer Elvia Pyburn-Wilk tells me of other ways of studying waiting in the sense of time wasted. For example, she writes that, while living in Sao Paulo, "I recorded the amount of time spent waiting on a particular street corner every morning while waiting for the lights to change. Then at the end of the week I went back to the corner and waited for the cumulative amount of time for that week in order to 'cancel out' my wasted seconds." In this project she investigated her own reaction to the transformation of several ordinary waiting moments, measured in seconds, into a calculated period of superfluous activity. Like Wikström, Khan and Lee, such projects by Pyburn-Wilk intensify the experience of an inconspicuous everyday situation and make us to see it in a new way, perhaps with astonishment or with a smile of recognition.
} 
inspired by the work of contemporary artists - how can their methods contribute to our cultural research in more substantial ways? ${ }^{3}$

\section{Spatial questions}

Many artists worldwide have become increasingly preoccupied with producing knowledge of various kinds. Both they and their curators are using the same terminology as is used in the sculpture hall mentioned above. For example, in the old and dirty boiler room at the gallery Epidemic of Art (also in Gothenburg) a young Swedish artist, Ossian Gustafsson, has fastened many blue nylon cords between the walls in parallel patterns. He writes:

My work is about spatial problems. With a specific place as a starting point I investigate the visual and space-producing qualities of the material in the encounter with the spectator.

Physical experience and observation are recurrent themes in my installations.

So how should we interpret this artwork? For me, words like "problems" and "investigate" create an expectation of intellectual understanding that I don't get at once. But I can see that the nylon cords transform the boiler room. For example, you have to crouch down below them as though they were laser beams protecting objects in a vault. Other people's impressions are different. One entry in the gallery's visitors' book reads: "Nice! I start to think about rain from different directions." Meanwhile another visitor comments: "Wow! A lot happens in my eyes when I look straight into the cords."

The exhibition Investigation of a Dog, in a disused shipping warehouse, Magasin 3 in Stockholm, shows work by 30 internationally known artists. The catalogue describes all of them as "investigating", "researching" or "analysing" various existential or political issues. For example, a film by Mircea Cantor depicts a group of people walking through the Albanian capital, Tirana, carrying large mirrors as demonstration placards. The curator explains that Cantor is "investigating the effect of rebellious actions on complex political and bureaucratic systems".

Despite being an enthusiastic art lover, without the curator's explanation I would not really have understood what Cantor was investigating. Instead I would merely have been fascinated by the reflections in the large mirrors of urban scenes in Tirana and by how little attention the demonstrators attracted from other people. Artistic research evidently demands more brain work than that.

At another Stockholm art gallery, in the suburb of Haninge, I visit RUN'n JUMPS - the faith in human electricity, an installation by the Norwegian artist Tori Wrånes. The gallery information describes Wrånes as "researching the physical possibilities of the voice and the space of the room with video, photography and sculpture". The room is the artist's own studio, "an amoeba which is living and breathing in endless motion". On one wall a film is being projected showing the artist leaping around her studio among all her things. Another wall displays photographs of the same actions. Two pairs of jeans hang from the ceiling to form a sculpture with the legs going in opposite directions.

\footnotetext{
${ }^{3}$ This question has been examined by other researchers. For example, Nigel Thrift (2004) refers to works by the video artist Bill Viola in a theoretical discussion about politics and emotions. Among Swedish ethnologists, Robert Willim $(2009,2010)$ has produced several art films combining art and ethnography (see http://robertwillim.com/transmutations-of-nature). Another art-inspired ethnologist is Erik Ottoson (2008), whose dissertation about different forms of shopping describes how he practised the psycho-geographic methods of the French situationists by drifting around in urban surroundings to see how they affected his emotions and perception of atmosphere.
} 
First of all the curator, Johanne Nordby Wernø, tells us what fun it has been to work with the rebellious and humorous artist and how she, together with technicians and carpenters, worked with Wrånes for a whole week installing the exhibition. Suddenly the gallery blacks out and Tori Wrånes, wearing a black dress, enters and sits down at a piano. A thick, long rubber tongue emerges from her mouth and curls down to the floor. Wrånes plays a simple melody and hums a song for five minutes. Then she stands up and leaves the room.

In an attempt to find out more about the meaning of Wrånes" "research of the space" and the kind of knowledge it has produced, I write to the curator. My letter also asks about the relationship between the song and the installation. Soon after I receive a long reply that, among other things, explains that Wrånes is investigating how her voice is affected by the rubber tongue. It also explains that when Wrånes leaps around in her studio, she wants viewers to see the space in a new way. Now I understand that this is another way of taking possession of the space, just as Ossian Gustafsson took possession of it with his nylon cords in the boiler room and as Mircea Cantor did with his demonstrators and their mirror placards in Tirana.

But I am still a little confused, which probably means that my interpretation of the concepts of research and knowledge is too narrow in this context. While, as an ethnologist, I am certainly often using rather subjective methods that researchers in other disciplines may view with scepticism, I am also trained in logical, scientific thinking. At the same time I know very well that there are many other ways of searching for knowledge, such as, for example, practical, sensual and emotional ways. So in the end I should not really have any trouble with the artistic research methods.

\section{Researching suggestion}

At Tensta Gallery, north of Stockholm, I enter a room with red velvet drapes on the walls and furnished with a standard lamp beside a green armchair. A set of headphones hangs from the ceiling. When I put them on and sit down the light goes out. In the darkness I suddenly hear someone approaching in high-heeled shoes. I start and look round. There is no one there. Even so, I feel someone leaning over my left shoulder and a woman's voice begins to tell a spooky story about something that happened to her father during the war. Her mouth is close to my ear, I can hear her breathing. After a while she moves to my right ear. Several times I look around. When the story is finished the woman leaves the room, her heels clattering sharply on the floor. There is silence and the light comes back on. I had experienced Hans Rosenström's sound installation Her Presence Still. Before I leave the gallery, I sit down in the armchair three more times to relive this horrible experience.

If we consider this artwork as a piece of research, it would appear to be using objects, light and sound to research the phenomenon of suggestion. Suggestion - where reality is produced through the common power of imagination - is fundamental to all social life. My disturbing art gallery experience in fact represents what happens between people every day: we all are deceiving each other and ourselves about what is going on, about what we want and think, and about where we spend our time mentally while daydreaming. With varying degrees of self-awareness, we control the impressions we give to others and present ourselves in different ways. We tell contrived stories and manipulate situations. Secrets are used to conceal truths. Here both artists and cultural researchers have an important task - to investigate the power of the imagination both as individual escape attempt and as social cohesive. 
Art works that have a powerful effect, such as Her Presence Still, have a tendency to remain in the mind, not only as memories and frames of reference, but also as worrying reminders that existence is not what it appears to be. Art critics and art historians write endlessly about this topic, but my intention in approaching these works is different. I want to learn more about new ways to search for and communicate knowledge.

\section{Research on artistic ground}

Several European universities offer artists the opportunity to gain doctoral degrees in their own work, for example, in visual arts, sculpture, music, and dance. In Sweden, a dozen doctoral theses of this kind have been produced since $2006 .{ }^{4}$ Moreover, it is also possible to apply for research grants to undertake artistic research that combines creative work with documentation and analysis.

Unsurprisingly, this new area of academic research has met with some scepticism from established fields. Disbelief among natural scientists, however, has perhaps been more subdued than one might have expected. In fact, there seems to be hope among scientists that artists will help elucidate new aspects of the scientific process. In general, "disciplinary anxiety" has been more marked within closely related academic areas. What is this hybrid that may shake up existing conceptions of what research - and art - is and should be?

Literature on the subject of artistic research is growing fast. Graeme Sullivan (2005), Mika Hannula et al. (2005) and Per Nilsson (2009) are among those who claim that the arts should apply their own criteria in seeking knowledge. ${ }^{5}$ Why? Because artists in their work both experience and investigate the world. Artists lay no claim to pursue conventional science leading to empirical knowledge and general conclusions. Instead their work may increase our understanding of man as a culture-creating being, as well as questioning received wisdoms. In these efforts, an open exchange of ideas and experiences should be advantageous for both artists and traditional researchers (Nilsson 2009: 149 et seq.).

Artists' production of visual knowledge, or "discursive thought experiments" (Nilsson 2009: 45), involves the practice of many different methods and forms of presentation. The artist becomes a Jackof-all-trades, living experimentally and switching between the trades of theorist, producer, installer, writer, activist, and entertainer - and sometimes even shaman (Sullivan 2005: 4) ${ }^{6}$.

Anthropology is one academic discipline where artists and researchers are already cooperating all over the world (Marcus \& Myers 1995, Schneider \& Wright 2006, 2010). Artists are using ethnographic methods, such as interviews and fieldwork, to create their work, while anthropologists are utilising visual materials such as film, multimedia, theatre and installations to communicate knowledge. Practitioners in each of the fields are borrowing and learning from each other, without ignoring the differences.

\footnotetext{
${ }^{4}$ These include Leiderstam (2006), Yoshida (2006), and Bode \& Schmidt (2008). Others will be discussed later in this article.

${ }^{5}$ See also Balkema \& Slager (2004), Borgdorff (2009), Caduff, Siegenthaler \& Wälchli (2010), and Biggs \& Karlsson (2011).

${ }^{6}$ Dieter Lesage (2007) has written a rather entertaining portrayal of "the artist as researcher": a person who is a stranger to nothing and who moves freely between traditions, disciplines, professions, and nations.
} 
Such interdisciplinary cooperation is also found between the humanities and various artistic ITrelated enterprises. ${ }^{7}$ One specific example concerns a philosopher and a dancer who met regularly to learn from each other and to examine their own activity from the other's perspective (Mark \& Muchin 2010). While the dancer gained help from the philosopher in analysing her physical creation, the philosopher learned about physical movement from the dancer. Their experiences demonstrate that teamwork between an artist and a researcher is not necessarily a bed of roses. As well as playful creativity, the process also involved a power struggle about professional territories.

\section{To do what comes into one's mind}

How do you undertake research in art? While there is of course a host of different ways, in fact, a way for each artwork, it is nevertheless possible to outline at least two main alternatives. One is exemplified by Elin Wikström, professor of fine arts at Umeå University. In her project Cool or lame? which lasted for a whole year, she wore only clothes that she had made herself (Fig. 2). Another project involved standing outside an H\&M clothing store in Bremen, Germany, and trying to catch the customers' eyes as they entered or left the shop. The customers were also being filmed by Wikström. Subsequently Wikström travelled to Phnom Penh in Cambodia and filmed workers in a textile factory. Both films were shown to the textile workers and to customers at H\&M. For a third project Wikström enrolled eight women who agreed to live without electricity for several days, during which time they were filmed and interviewed by Wikström. These three artworks, focusing on the issues of consumption and the environment, as well as being events in themselves, also comprise the related documentation, media coverage, and follow-up discussions and seminars.

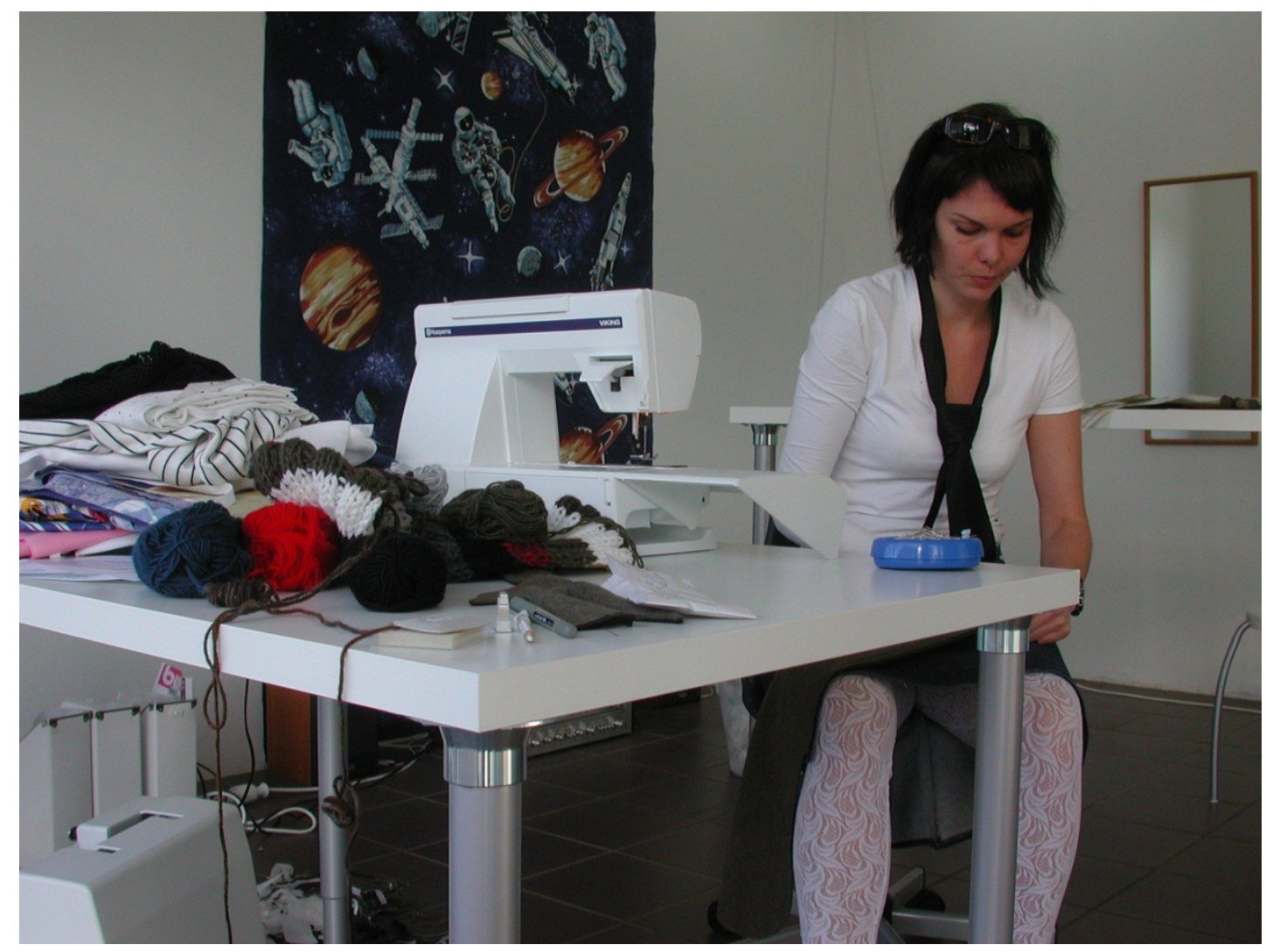

Figure 2. Elin Wikström, Cool or lame? (2003).

\footnotetext{
${ }^{7}$ One example is meeting places for new information technologies, such as HUMlab at Umeå University.
} 
In a book about these and other projects, Wikström (2009) and two of her fellow artists explain how they work. It turns out that their working processes roughly mimic those of cultural researchers: they ask questions, choose methods, read theories, make observations, carry out interviews, participate in various social events, surf on the net, collate their material, get new ideas, and examine different analytical angles of approach. They try to see the ordinary as something out-of-the-ordinary and practise autoethnography, using their own experiences as basic data. Apart from this they are also playful, following their intuition, and presenting their results in artistic forms. In some ways this sounds very familiar, in some ways not at all.

For example, what would a sociologist, anthropologist or ethnologist think of Elin Wikström's strategy for investigating racism, which involved three blacked-up white men walking around at a crowded public swimming pool? Or who would want to question established conventions by sitting naked, as she did, for six weeks in an armchair at an art gallery in a small town? These ways of undertaking artistic research involve carrying through extraordinary ideas that for most of us would never become more than fantasies. Many contemporary artists simply do whatever occurs to them, albeit with thorough and careful preparation. By comparison, university researchers have undoubtedly been more conservative - until now, when increasing numbers of artists are taking doctoral degrees.

\section{Three artistic dissertations}

As mentioned above, another way of doing artistic research is to write a doctoral dissertation about your own work. In Sweden, one of the first such dissertations was written by the architect and artist Monica Sand. Entitled Space in Motion - the Art of Activating Space In Between (in Swedish, 2008), it describes and analyses four of Sand's art projects. One involved installing a 42m-long swing below a bridge (Älvsborgsbron) in Gothenburg harbour. The idea was realised with the competence and attention to detail of an engineering project. The dissertation describes the project in detail as a collective performance in a public space. The installation was filmed and shown at other exhibitions where viewers were allowed to try smaller swings.

One purpose of this dissertation was to develop tools for analysing architecture. Another was to argue for the importance of artistic research, while a third was to analyse often overlooked spaces "in between". Sand takes as her starting point the myth of Penelope weaving at her loom while waiting for Ulysses. This Penelope figure is then used throughout the text to illustrate various ideas about rhythm, repetition and spaces in between.

These concepts are also discussed in the context of three other disparate projects: a walk with art students through a deserted railway tunnel in Stockholm; an investigation of the spatial organization of CERN (the particle physics laboratory outside Geneva); and finally a dance event that combined art and physics. The research problems are concrete in nature. How do you install a swing under a high bridge and have a dancer swing in it? What do you experience during a walk in a deserted tunnel? What does CERN look like and what are the physicists doing in the laboratories? How can a dance performance be created as a commentary on particle physics?

Among other things, Sand wants to show how different actors are moulded by the process of interaction with their tools or machines. Penelope uses her loom as a time machine. The swing and the bridge together form a machine that creates experiences. The act of walking in the tunnel brings to life one of the dormant possibilities of the city. Particle physicists build machinery for interpretation. The dance constructs a rhythmic source of energy around time and space. 
These projects realise artistic ideas through theoretical writing, as well as through practical work with people and things. The research results are not only intellectual knowledge, but also emotional experiences. Everyday activities like walking and swinging are endowed with unexpected meanings. The act of bringing together dancers and physicists is in itself surprising.

Another example is conceptual artist Magnus Bärtås' dissertation You Told Me - Work Stories and Video Essays (2010), which among other things discusses the significance of the narrative in contemporary art. A CD enclosed with the dissertation contains five "video essays" (films) about artists and film-makers in Croatia, Japan and North Korea.

Following a long introduction about theory and method, the main body of the work consists of lively "work stories" about the production of the films. The leading characters are all original and creative persons. Bärtås has collaborated with one of them, an artist who is staying with his elderly parents in Zagreb, to create the website The Resort of Homeless Ideas, which welcomes all unrealised projects. In another film, about the eccentric Tokyo art agent Johnny Walker and his gigantic Irish sheepdog, an old woman from Manchuria is engaged as narrator. The third film concerns a directorcum-actress, who was kidnapped by North Korean agents to make a propaganda movie for Kim Jong II. The narratives of these films are in themselves literary artworks that mix fiction and documentary reports. Their basis is ethnographic fieldwork that seems directed by the reporter/author's search for the exceptional, rather than the questions a cultural researcher would pose about the typical in everyday life.

A third example is Carola Wingren's dissertation The Artistic Practice of a Landscape Architect - Knowledge Development through an Autobiographical Study (in Swedish, 2009). Wingren had already been running her own landscape architecture practice for many years when she started work on her doctoral degree. In her dissertation she describes the creation of various projects, in particular a water park in Malmö. She describes the aim of her dissertation as being to see through the veil of unarticulated knowledge behind which artistic practice often hides. Wingren describes in detail her everyday work, including everything from informal sketches to the finished result in the form of a changed landscape. In these reflexive "work stories" she utilises diary notes from her childhood onward. Like Sand, she works as an artist in collaboration with a number of other professionals, such as planners, designers, carpenters, pavers, gardeners and excavator drivers. These collaborations require artistic considerations to be coordinated with economic and practical demands.

In the artistic side of her work, Wingren uses a wide range of methods. To illustrate her ideas for the park she goes to hobby shops and buys plastics, textiles, beeswax and silk roses. She also gets miniature dolls to place in the model landscape. Her inspiration comes from a variety of sources: novels, mountain tours, and childhood memories of the bogs in western Sweden.

One method tried out by Wingren involves writing a short story about a girl wandering aimlessly around in the park with her boyfriend one autumn day. How does she experience the park? Other methods involve role play and workshops. When Wingren is planning how to approach a city, she builds an installation. The water in the small river under the road is represented by thick planks countersunk in asphalt to recreate the sound you hear when driving over a wooden bridge.

\section{Method and confusion}

Compared to most academic theses, it should be obvious that these three doctoral dissertations are rather unconventional. Quite simply, the artists tend to use more subjective and experimental ways of searching for knowledge. At the same time, several of the techniques they employ are well-known to 
cultural researchers in the field of ethnography. The artists switch between a close inspection of the ordinary and a more distant theoretical analysis ${ }^{8}$ in a research process that may sometimes comprise a combination of method and confusion. In fact, many cultural researchers are doing similar things, but in different ways.

One factor common to all three dissertations is their work stories: the artists' descriptions of the practical circumstances surrounding their projects, such as the film-maker's adventurous travels or the landscape architect's practice of playing around with diverse objects. The story about the swing under the bridge describes the winds, the darkness and the winter cold, but also the camaraderie of the working team, the precise calculations, the long-winded negotiations with the authorities, the discussions with the dancer who was going to perform on the swing, the traffic thundering overhead on the bridge, and the curious passers-by watching from footpath. In other words, both the artwork and the research process were characterised by many sensory experiences.

The descriptions of working with the projects involving the swing, the films and the park all show in a concrete manner how it is possible to combine unrestrained ideas with solid craftsmanship and wide-ranging social skills. Obviously these artistic researchers are also bold entrepreneurs. Survival in the tough art market requires special talents, as well as team-working abilities, media savinness and common sense. While the project may be conceived in the studio, subsequently it will be put to the test by people in real-life. Here the artistic researcher may encounter down-to-earth conditions that present challenges and lead the creative process in unexpected directions. In this way the artist becomes a committed actor - a person who changes observed reality rather than simply participating as a thoughtful spectator.

\section{Alternative knowledge production}

So far in this article I have reflected on ways in which cultural researchers may relate to contemporary art. One way is to be affected emotionally. When I saw Ulf Rollof's Bellows IV I was amused. Smiling I examined how the "cannon" was made and was also impressed by the artist's imagination and skill. At the time I did not think about the philosophical questions the artwork raised or how it influenced my way of looking at reality.

But in order really to adopt the strategies of artistic research, this approach is not enough. Instead art has to be seen as an alternative form of knowledge production, one that to some extent has its own aims, rules and methods. It is also necessary to ask what it accomplishes. Of course, this does not mean that cultural analysts should either start working as artists or totally reconsider their traditional views on knowledge. Art and science should still be perceived as disparate activities, with artists probably borrowing more from science than the other way around. But where might a more open exchange between artists and scientists lead?

At the beginning of this article I mentioned three art projects that provided new perspectives on waiting as a physical activity filled with elusive meanings. In particular these works exemplified the artists' ability to see ordinary life anew. But there are still other things left to learn from artists and in the following I try to pin these down by looking at four other art projects. Each revolves around the same theme: the home and its heartbreaking materiality. Homes and houses are, of course, old favourites as subject-matter for cultural analysis. Much has been written about them from the

\footnotetext{
${ }^{8}$ The analysis is based on the work of frequently referred to thinkers such as Foucault, de Certeau, Butler, Latour, Haraway, Ahmed, and Deleuze \& Guattari.
} 
perspectives of family, gender, consumption, and social class. However, the following artists have somewhat different viewpoints.

In his installation/performance Break Down, Michael Landy destroyed all his possessions in an extremely systematic - even bureaucratic - manner. All of the 7,227 things that he owned - from his SAAB 900 to a single postage stamp - were gathered at a disused London department store. There they were categorised, entered onto a database, labelled, and bagged. Assisted by a team of helpers on a factory-style production line, Landy set about reducing everything to its component materials. Finally these were crushed and granulated beyond recognition.

In her installation Unheimlich Manöver, Klara Lidén piled all her belongings from her Stockholm apartment into a high barricade, consisting of worn, dirty and banal objects. In The Garbage Man, Ilya Kabakov nailed thousands of small items - mostly garbage saved from his Moscow home in the early 1980s - onto wooden screens (Fig. 3). All items were arranged in groups to form unique kinds of collections. Tiny labels were attached under each object: "a spare socket, it rolled under the cabinet and I found it only last spring, in March", "plaster from the crack in the windowsill", "medicine, don't remember for what", "sardine can, bought for October 7, consumed with Nikolai", and so on.

While Landy destroyed all his belongings and Lidén squeezed them together, Kabakov transformed his home into a scientifically ordered museum or collection of curios. A fourth method was practised by Martha Rosler in her film Semiotics of the Kitchen. Here she stands in a kitchen, wearing a dress and apron. Deadly serious, she lifts up seemingly harmless kitchen utensils, one after the other, and with violent movements demonstrates how they can be used as murder weapons.

What is so interesting about all this for a cultural researcher? Although each artwork described in the above seems to have its own unique methodology, there are some common factors that I will highlight in attempting to provide a conclusive answer to that question. One is that the artists are making use of themselves both as actors and as research objects. They are living experimentally and their actions have obvious consequences for their lives, for example, in clearing out their homes. They film themselves and deal with deeply personal questions. Perhaps some of them should say, as did Allan Pettersson in the opening quotation, "My art is my life, my own life, my way of living, the blessed and damned life, nothing else."

Cultural researchers like me do not usually go as far as that, even though we do make use of ourselves to collect and analyse material. Accordingly there is something for us to learn from artists' experiences in our own methodological discussions about participant observation and reflexivity. How deeply affected are we by the subjects we are researching? What kinds of traces are we leaving in their lives?

Secondly, contemporary art works approach the issue of materiality in very tangible ways. These artists are physically active when dealing with objects of different kinds. They grub and tear, they build, destroy, sort and squeeze. They pick up sardine tins and shirt buttons and lift heavy pieces of furniture. Here the artistic investigation of the home becomes a demanding toil that detaches things from their place and releases them from their ordinary functions. Bicycles, CDs and tubes of toothpaste suddenly find themselves belonging together.

Materiality has recently become a hot topic among cultural researchers, always eager to find new analytical viewpoints. However, thinking and writing about things is quite different from doing something practical with them, as many artists do when utilizing their inquisitive and corporeal methods. Cultural analysis of sofas or lawn mowers is usually undertaken at a safe distance from the 
actual objects and leaves them untouched. Artists do not seem to be constrained by any such reverence. Their listing of things may resemble a scientific method, but in fact gives more the impression of a parody. ${ }^{9}$ Perhaps even cultural researchers should sometimes dare to be more blasphemous and see what happens.

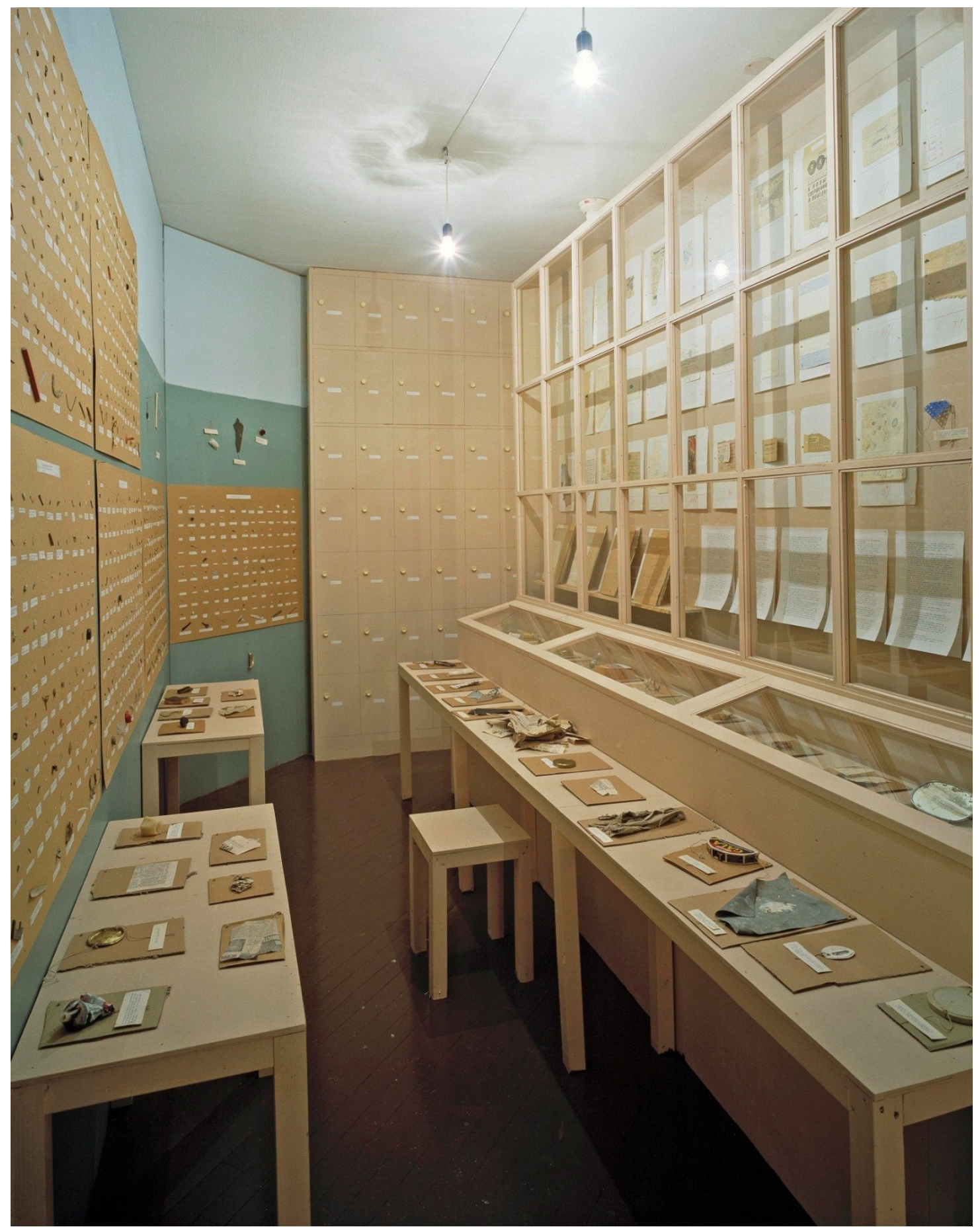

Figure 3. Ilya Kabakov, The Garbage Man (1995).

\footnotetext{
${ }^{9}$ The former social anthropologist Susan Hiller is one artist engaged in collecting, arranging and classifying everyday objects in various installations and performances. Her "paraconceptual" art makes fun of scientific efforts to chart the world (Gallagher 2011: 19).
} 
Another relevant field of cultural analysis is emotional life. Here the artists are not satisfied simply to describe and analyse feelings; instead they want to produce actual experiences. They want to amuse, to worry or to provoke. Seeing the contents of a home transformed into a heap of dust is bewildering, as is the sight of everything from an old apartment being gathered together and catalogued. When I watched the film of Martha Rosler standing in the kitchen and enacting the striking of a mortal blow with the ladle, I gave an uneasy laugh. At home I suddenly experienced the things in my kitchen drawers and cabinets in an ominous way.

Much of contemporary art is indeed emotional - even when it is called conceptual - when it comes to its creation, forms of presentation, and influence on the viewer. When artists systematically implement wild whims they are exploiting their spontaneity professionally. The very idea of demolishing, cataloguing or exhibiting your belongings could - I imagine - provoke a maelstrom of passions and impulses, at least for a time. For a cultural researcher this raises questions about the significance of one's own emotions in the production of knowledge. Should they be ignored to give an impression of objectivity or should they be used as an exploratory resource?

Finally, artists are gifted with the ability to find and communicate surprising meanings in ordinary life - this is certainly something that many cultural researchers very much want to do. Artists accomplish this by working patiently with whatever they have to hand. They stare at it, tear at it and turn it over again and again, until finally something begins to happen. They investigate and film their "stuff"; they read, theorise and talk about it. During this process of metamorphosis, some things are enlarged while others are miniaturised. Still others are stylised, and in the end the objects are estranged from the familiar. Practical deeds, as well as emotional and intellectual work, are crucial to the creation of the artworks. Carrying out wild ideas in public not only calls for fantasy and wilfulness, it also requires orderly methods.

This manner of working is not, as already mentioned, totally unfamiliar to cultural researchers. The process of collecting material, analysing it, and writing a text is rather reminiscent of artists' oscillations between systematic endeavours and capricious playfulness. Periods of Sturm und Drang alternate with periods of indolence. All of a sudden you may have a flash of genius and be inspired to work. But artists do seem to have a special ability to extract grains of gold from chaff. How on earth do they do this?

In these four methodological areas, I think an open exchange between artists and cultural researchers would be productive. However, living experimentally, working physically, exploiting spontaneity, and seeing things that other people simply do not see, are all experience-based skills that can't be acquired entirely (or not at all) by intellectual efforts. A great deal of practice is required to realign your habitual way of thinking.

Many cultural researchers have used, with varying degrees of systematisation, artistic methods such as transformation and experimentation. Some, of course, also utilise visual means such as pictures and films to present knowledge. Even fiction and fantasy may be important tools, as well as aimless searching (serendipity). But researchers in general tend to be more compliant than artists when it comes to scholarly requirements. However, since the purpose is to produce new knowledge and understanding, one must sometimes dare to try ways that defy prevailing norms and perhaps break some academic rules. By taking inspiration from artistic methods, it should be possible to produce more surprising cultural analysis.

Exactly how this will be achieved is, of course, difficult to predict. Actually carrying out artistic experiments in cultural research is quite different to utilising them as clarifying illustrations. Even 
though all kinds of researchers are, at least in some parts of the investigative process, already working intuitively, most of them probably do not perceive this to be an essential part of their methodology. I think it is precisely in this regard that artists, with their combination of unbridled creativity and craft skills, may provide encouragement. In any event, it will be interesting to see the results of a more open exchange between artists and cultural researchers in the future.

\section{Presentation of contributor}

Billy Ehn is professor of ethnology at the Department of Culture and Media, Umeå University. He has mainly engaged in ethnographic and cultural studies, based on field work in various environments, in the former Yugoslavia, in Poland, at a pharmaceutical plant and at various preschools in and around Stockholm. His latest book is The Secret World of Doing Nothing (University of California Press, 2010, with Orvar Löfgren).

\section{Referenced artworks}

Mircea Cantor, The Landscape is Changing (2003), film, Magasin 3, Stockholm. Ossian Gustafsson, Untitled (2011), installation, the Gallery Epidemic of Art, Gothenburg. Ilya Kabakov, The Garbage Man (1995), installation, The Museum of Contemporary Art, Oslo. Akram Khan, Bahok (2008), dance performance.

Michael Landy, Break Down (2001), installation and performance, London. Hatty Lee, Waiting Room (2000), installation and photography, Mjellby Art Gallery, Klara Lidén, Unheimlich Manöver (2011), installation, Moderna Museet, Stockholm. Ulf Rollof, Bälg IV/Bellows IV (1989), sculpture, Gothenburg Museum of Art. Hans Rosenström, Her Presence Still (2011), sound installation, Tensta Art Gallery. Martha Rosler, Semiotics of the Kitchen (1975), film, Moderna Museet, Stockholm.

Elin Wikström, "Rebecka is waiting for Anna, Anna is waiting for Cecilia, Cecilia is waiting for Marie..." (1994), performance, Moderna Museet, Stockholm; Half Being Half Flow (20032004), performance and film, Bremen and Phnom Penh; Cool or Lame? (2003) Galleri Brändström \& Stene, Stockholm; A Few Planets More (2006), performance, Stockholm; Untitled (2010), performance, Alingsås Art Gallery; Gunde, Erling och Kjell - tre flitiga, lugna och fina svenska män som hellre arbetar än lever på bidrag och respekterar kvinnor/Gunde, Erling and Kjell three diligent, quiet and good-looking Swedish men who prefer to work rather than to live on benefits and who respect women (1999), performance, Karlskrona Public Baths, Karlskrona.

Tori Wrånes, RUN'n JUMPS - belief in human electricity (2011), installation and performance, Haninge Art Gallery.

\section{References}

Balkema, A. \& Slager, H. (eds). (2004). Artistic Research. Amsterdam: Rodopi.

Biggs, Mi. \& Karlsson, H. (eds). 2011. The Routledge Companion to Research in Arts. London: Routledge.

Bode, M. \& Schmidt, S. (2008). Off the Grid. (Dissertation.) Gothenburg: Valand School of Fine Arts.

Borgdorff, H. (2009). Artistic Research within the Fields of Science. Bergen: National Academy of the Arts.

Bärtås, M. (2010). You Told Me - Work Stories and Video Essays/Verkberättelser och videoessäer. (Dissertation.) Gothenburg: ArtMonitor.

Caduff, C.,Siegenthaler, F. \& Wälchli, T. (eds.). (2010). Art and Artistic Research. Zurich: Scheidegger \& Speiss.

Denzin, N. \& Lincoln, Y. (eds). 2005. The Sage Handbook of Qualitative Research. Thousand Oaks, California: Sage. 
Ehn, B. \& Löfgren, O. (2010). The Secret World of Doing Nothing. Berkeley, California: University of California Press.

Ehn, B. \& Löfgren, O. (2011). Å fange det unnflyende. Kulturanalytisk bricolage som metode. In: Fangen, Katrine \& Ann Mari Sellerberg (eds), Mange ulike metoder. Oslo: Gyldendal.

Foster, Hal, (1995). The Artist as Ethnographer? In: Marcus, George E. \& Fred R. Myers (eds). The Traffic in Culture. Refiguring Art and Anthropology. Berkeley: University of California Press.

Gallagher, Ann (ed.). (2011). Susan Hiller. London: Tate Publishing.

Hannula, M., Suoranta, J. \& Vadén, T. (2005). Artistic Research - Theories, Methods and Practices. Gothenburg: ArtMonitor.

Kabakov, I. (1995). The Garbage Man. Oslo: National Museum of Contemporary Art, Oslo.

Krappala, M. (1999). Burning (of) Ethics of the Passions. Contemporary Art as Process. (Dissertation.) Helsinki: University of Art and Design.

Leiderstam, M. (2006). See and Seen: Seeing Landscape through Artistic Practice. (Dissertation.) Malmö: Malmö Academies of Performing Arts, Lund University.

Lesage, D. (2007). A Portrait of the Artist as a Researcher. Accessed from www.summit.kein.org/node/233

Marcus, G. E. \& Myers, F. R. (eds). (1995). The Traffic in Culture. Refiguring Art and Anthropology. Berkeley: University of California Press.

Mark, E. \& Muchin, P. (2010). Teorier ur kroppsliga praktiker. Stockholm: Carlssons.

Nilsson, P. (2009). The Amphibian Stand. A Philosophical Essay Concerning Research Processes in Fine Art. Umeå: h:ström.

Ottoson, E. (2008). Söka sitt. Om möten mellan människor och föremål. (Dissertation.) Uppsala: Etnologiska avdelningen, University of Uppsala.

Rist, P. (2007). Congratulations! Stockholm: Magasin 3, Stockholms Konsthall.

Sand, M. (2008). Konsten att gunga. Experiment som aktiverar mellanrum. (Dissertation.) Stockholm: Axl Books.

Schneider, A. \& Wright, C. (eds). (2006). Contemporary Art and Anthropology. New York: Berg.

Schneider, A. \& Wright, C. (eds). (2010). Between Art and Anthropology. Contemporary Ethnographic Practice. New York: Berg.

Sullivan, G. (2005). Art Practice as Research. Inquiry in the Visual Arts. London: SAGE.

Thrift, N. (2004). Intensities of Feeling: Towards a Spatial Politics of Affect. Geografiska Annaler. Series B, Human Geography. Vol. 86, No. 1: 57-78.

Yoshida, M. (2006). The Invisible Landscape. The Construction of New Subjectivities in the Era of the Mobile Telephone. (Dissertation.) Malmö: Academies of Performing Arts, Lund University.

Wikström, E. (2009). Research Processes in Fine Art: Investigating the Investigation. Umeå: Academy of Fine Arts, Umeå University.

Willim, R. (2009). Två spår. RIG 2009/1: 24-27.

Willim, R. (2010). När nätet växer. Om algoritmiska och irreguljära metoder. http://natverket.etnologi.uu.se/volym/17/17_6.pdf

Wingren, C. (2009). En landskapsarkitekts konstnärliga praxis. Kunskapsutveckling via en självbiografisk studie. Alnarp: SLU. 